\title{
Strategic Management in the Implementation of Curriculum 2013 in Elementary School in Indonesia
}

\author{
Bettin Juniaria HS \\ Dept. of Educational Management, State University of Malang \\ Jl. Semarang 5, Malang 65145, Indonesia
}

Tel: 62-341-552-888 E-mail: bettinjuniaria@gmail.com

\begin{abstract}
Ahmad Sonhadji K.H.
Dept. of Technical Engineering, State University of Malang

Jl. Semarang 5, Malang 65145, Indonesia
\end{abstract}

Tel: 62-341-552-888 E-mail: asonhadjikh@yahoo.com

\section{Imron Arifin}

Dept. of Educational Administration, State University of Malang

Jl. Semarang 5, Malang 65145, Indonesia

Tel: 62-341-552-888 E-mail: ypas_malang@yahoo.com

$$
\text { M. Huda A.Y }
$$

Dept. of Educational Administration, State University of Malang

Jl. Semarang 5, Malang 65145, Indonesia

Tel: 62-341-552-888 E-mail: muhammad.huda.fip@um.ac.id

Received: July 7, 2017 Accepted: July 24, 2017 Published: July 26, 2017

doi:10.5296/ijld.v7i3.11504 URL: https://doi.org/10.5296/ijld.v7i3.11504 


\title{
Macrothink
}

\begin{abstract}
This study attempts at describing and explaining: (1) the strategic plan designing activity in the implementation of the 2013 curriculum; (2) the implementation of the strategic plans in the implementation of the 2013 curriculum; and (3) the evaluation on the implementation of the 2013 curriculum. This study employed a qualitative approach using the multi-case study design and the constant comparative method. The results of this study show that: (1) the strategic plans of the curriculum 2013 implementation was designed through these following steps; planning, the first step of the designing activity. (2) the implementation of the strategic plans which included 5 activities which were designing the curriculum documents, enhancement of teachers and employees' competences, the fulfillment of facilities, funding, and the improvement of school culture. (3) the evaluation on the curriculum implementation was done to measure the degree of success, problems, and solutions for the problems. By finding the solutions, problems faced by the schools can be regularly solved to prevent them from affecting the teaching and learning activities.
\end{abstract}

Keywords: Strategic management, curriculum, primary school 


\section{Introduction}

Primary schools hold an important role within the national education system since the primary schools run the basic education which becomes the foundation for the students to develop themselves to grow as excellent nation's generation. Sonhadji (2012) stated that primary school is a strategic formal education level which affects further level of education since it is the foundation for the middle school level. Therefore, improvement on the quality of primary schools is necessary to conduct. Bafadal (2012) also stated that primary schools should be well managed to perform high quality basic education. Primary schools are also education institutions that hold missions to achieve the institutional goals (institutional goals of national education). It implies that primary schools are said to have good quality when the schools are able to conduct their missions to achieve the institutional goals.

Primary schools are bounded to some other components one of which is the curriculum. Triwiyanto (2015) mentioned that the curriculum is the heart of the education. Not only it contains the goals that drive the students to achieve certain target, but it also contains the design of the content and how the teaching and learning should be conducted to equip the students with adequate knowledge, competence, skills and values that they will need in their future.

One of the most important aspects of the curriculum is the curriculum management. Curriculum management is important since it synergizes the elements of the curriculum with other components of education to achieve the national education goals. It is mentioned in the Rule of the Republic of Indonesia Number 13 of 2015 on the second revision of the Rule Number 19 of 2005 about the National Education Standard in which curriculum is seen as a set of plans which includes the goals, content and the teaching and learning materials as well as guidance to administer the teaching and learning activity to achieve certain targets.

The researcher is interested in conducting a study on the strategic management applied to the implementation of the 2013 curriculum in the target primary schools since: (1) few studies have been conducted on the strategic management applied in primary schools, (2) study on the strategic management applied to the implementation of the 2013 curriculum is a novel and up to date issue since there has not yet any studies on the matter available, (3) unique issues were captured in the preliminary study related to the strategic plans and the teaching and learning system in the target primary schools. In addition, SDN Blimbing was chosen as the representative of state-owned primary schools, SD Insan Amanah as the sample of Islamic school, and SD Mardi Wiyata 2 as the one that represents the catholic primary schools. Those schools are considered as the most appropriate samples to use in this qualitative study with multi-case design.

The focus of this study includes: (1) Understanding the process of designing the strategic plans applied to the implementation of the curriculum 2013 which covers: a) planning step, b) designing step (review on the vision, missions, goals, internal analysis, designing the programs and plans, arranging the funding plans and funding source, and determining he monitoring and evaluation system and c) the legalization of the plans; (2) the implementation of the predetermined strategic managements toward the 2013 curriculum that covers: a) 


\section{Macrothink

arrangement of the curriculum documents; b) the improvement of teachers and educators' capability; c) fulfillment of the facilities, d) funding and e) the change of the school culture and (3) the evaluation on the application of the strategic management in the implementation of the 2013 curriculum that covers: a) the success of the 2013 curriculum implementation; b) problems found during the implementation of the 2013 curriculum; and c) solutions for the problems.

\section{Methods}

This study was administered in three primary schools in Indonesia: SD Negeri Blimbing 3 Malang, SD Insan Amanah Malang, and SD Katolik Mardiwiyata 2 Malang. The data collection was done using three techniques: (1) in-depth interview, (2) participative observation, and (3) document analysis. The obtained data were then analyzed within two steps: individual-case analysis and cross-case analysis. In order to guarantee the validity of the data, credibility, transferability and confirmability tests were administered.

\section{Results}

3.1. The Designing Process of the Strategic Plans for the Implementation of the 2013 Curriculum

From those three cases, it is found that the schools implemented similar process, namely, planning, designing, and legalizing. Firstly, the planning step refers to the creation of a special team to design the plan appointed by the principle which members involved the representative of the school stakeholders. The team then started to work on the plan. Secondly, the designing step was initiated by reviewing the visions, missions, school goals, environment analysis, determining the programs and events, determining the funding and the source, determining the monitoring and evaluation system which data were documented in the form of a book. Thirdly, the legalization step which marked that the document had been legalized and it is ready to use as the guidance for the implementation of the program. The legalization was done by the schools which involved the school committee and the Head of the Department of Education, Malang.

The result of the cross-case analysis on the school characteristics with high competence and business-knowledge are presented in Figure 1. 


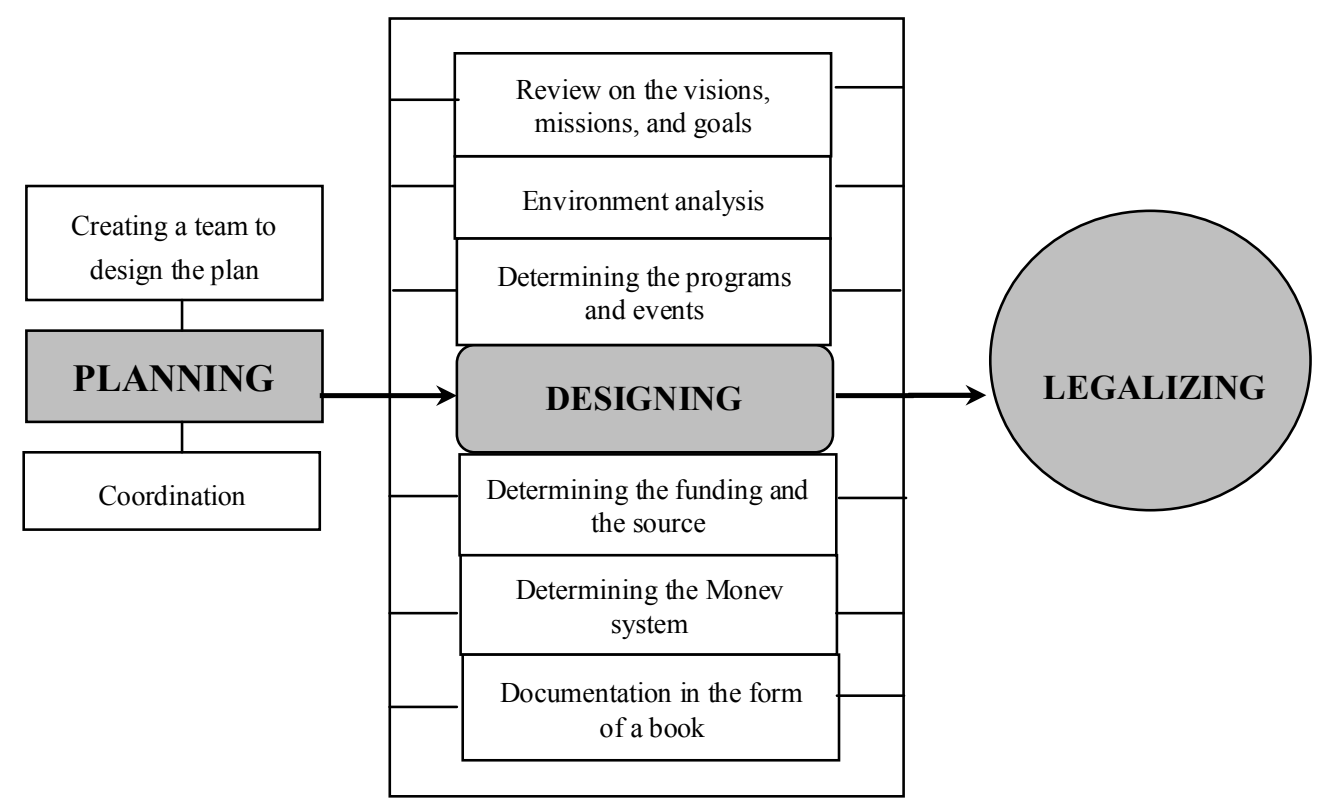

Figure 1. The Process of Designing the Strategic Plans for the Implementation of the 2013 Curriculum

3.2 The Application of the Predetermined Strategies in the Implementation of the 2013 Curriculum

The application of the strategic plans in the implementation of the 2013 curriculum covers five points that include the process to design the curriculum documents, improvement of the teachers and educators' capability, the fulfillment of the facilities, funding system and the change on the school culture. Each of the aspect is explained as follows. Firstly, the curriculum document was created by the Tim Pengembang Kurikulum (TPK)/the curriculum development team in which the document contains; a) visions, missions and goals; b) structure and the content of the curriculum; c) teaching and learning expense; d) standards of class promotion, mutation, graduation, treatments for non-promoted students and e) academic calendar. Secondly, the document contains information related to the number of teachers and educators and workshop trainings that can be held to improve their capability. Thirdly, it also contains the appropriate facilities that support the teaching and learning activity. Fourth, the determination of the funding sources such as funding from the government, social corporation, donation, business center, and other earnings. Meanwhile, the utilization of the fund is divided into direct cost, indirect cost, and other costs. Fifth, the change on the school culture is identified from the culture of the environment, reading habit, school culture, Islamic culture as well as achievements and Mardiwiyata knowledge. In order to grow good culture, schools apply rules for teachers, employees, and for the students.

The result of this section is illustrated in Figure 2. 


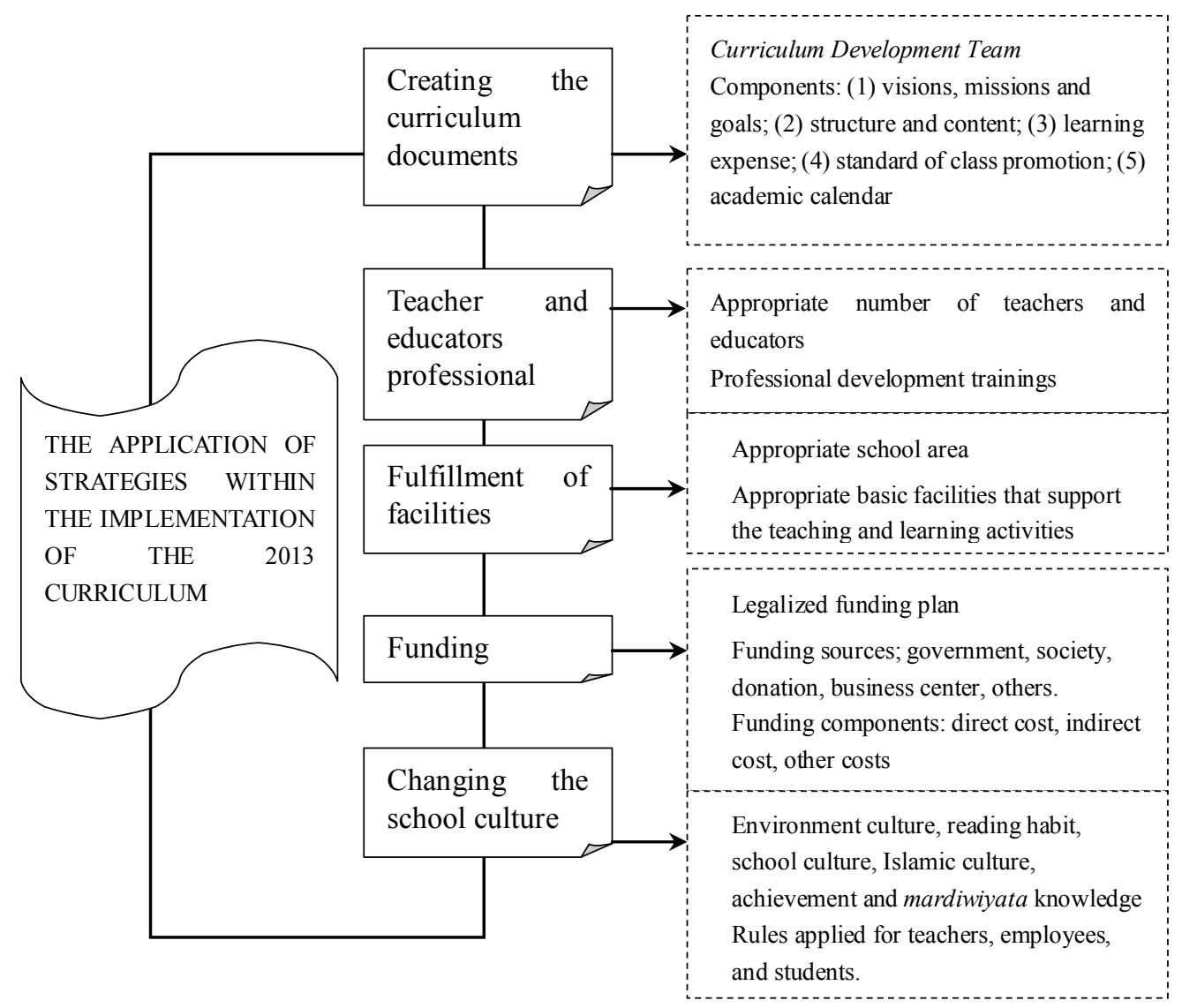

Figure 2. The Strategy Application within the Implementation of the 2013 Curriculum

\subsection{Evaluation on the Strategy Applied in the Implementation of the 2013 Curriculum}

Out of those three cases, it can be seen that there were three aspects to consider in the evaluation of the 2013 curriculum implementation: the degree of success, problems, and solutions. Fistly, the success of the 2013 curriculum implementation covered: adequate socialization; preciseness between the implementation to the plan, principles and the procedure; Material analysis; appropriate lesson planning; the use of effective and efficient teaching approach and method; Authentic asseessment; coordination, the community of target primary school for 2013 curriculum; and Report approporiateness. Secondly, problems faced during the implementation of 2013 curriculum included; Shifting the mindset; Limited preparation time; Material development that still needed enhancement; Insufficient teaching media; Inappropriateness use of evaluation techniques; and the management of programs and fund. Thirdly, the solutions toward those problems were; Administering special training for teachers and employees; Enhancing teachers' performance; Scale of priority; Reviewing the materials and creating modules; Non-stop innovations; Implementation of theme-based evaluation. 


\section{Macrothink}

The result of the cross-case evaluation on the implementation of 2013 curriculum is presented in Figure 3.

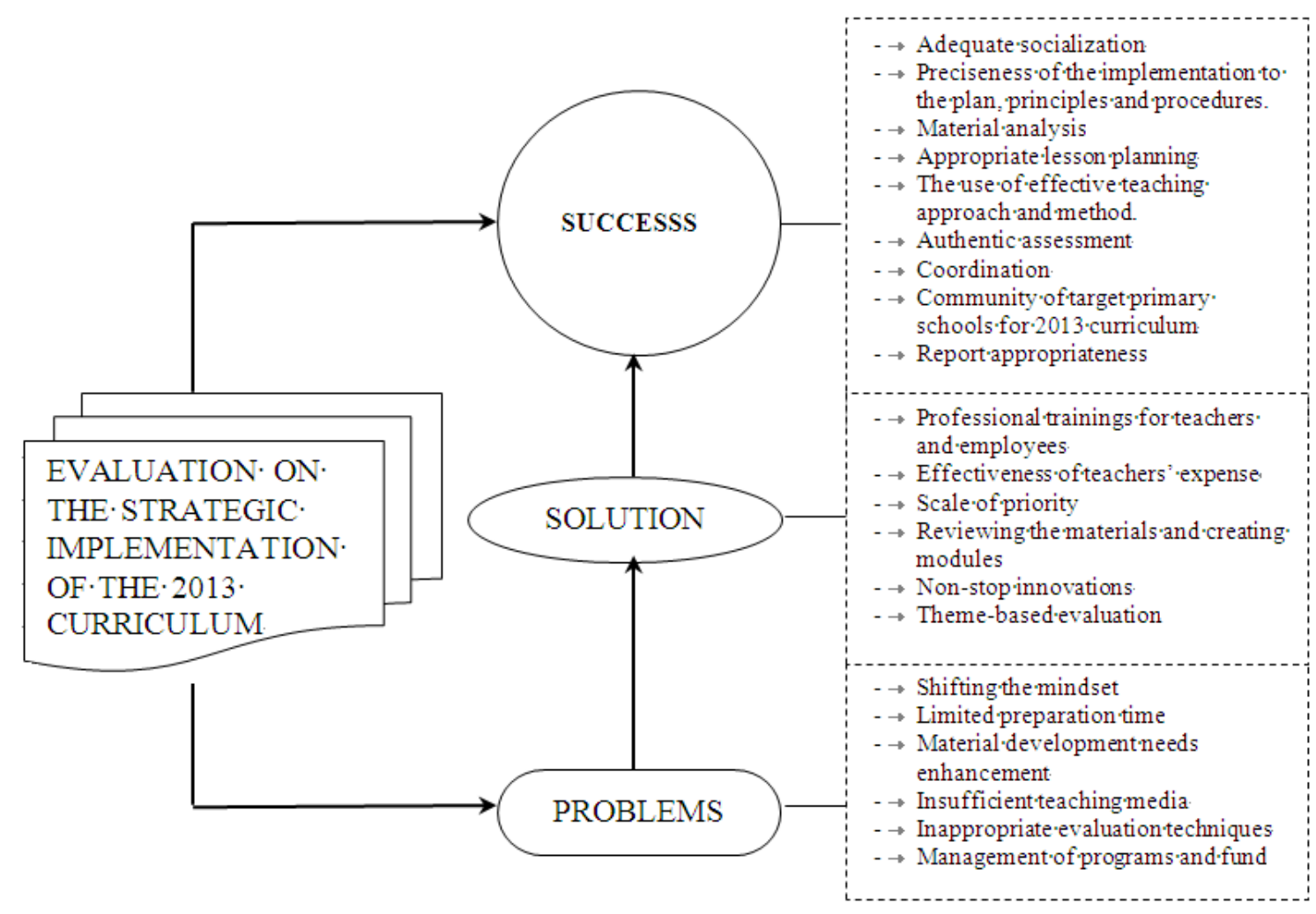

Figure 3. Evaluation on the Strategy Used in the Implementation of the 2013 Curriculum

Based on the results on: 1) the process of designing strategic plans of the 2013 curriculum; 2) the implementation of the strategy to the 2013 curriculum, and 3) evaluation on the strategy used in the implementation of the 2013 curriculum, the researcher present the result of the study on the strategic management in the implementation of the 2013 curriculum in primary school, especially schools which participated as the target in the pilot project as shown in Figure 4. 


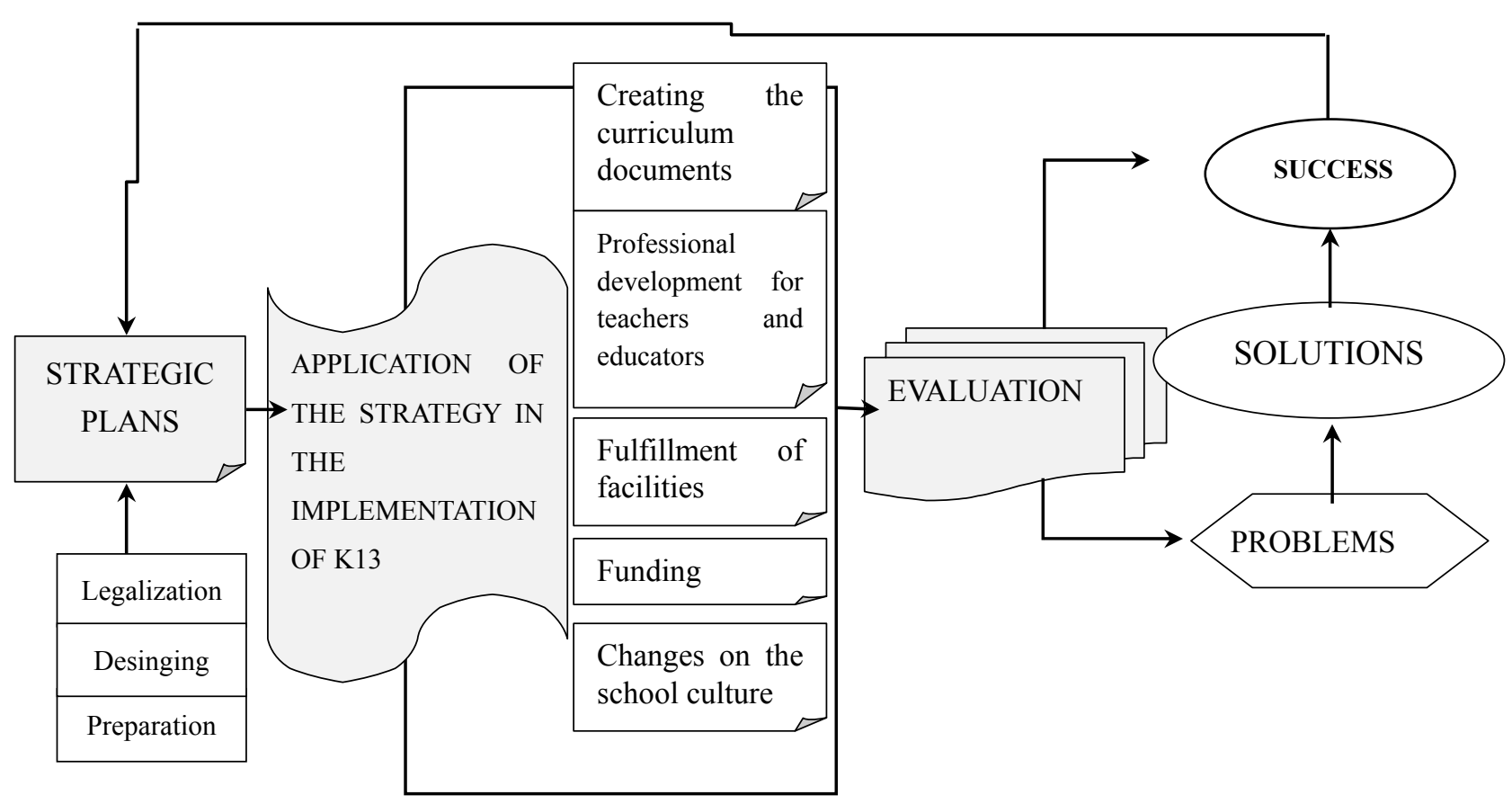

Figure 4. The Strategic Management in the Implementation of the 2013 Curriculum

\section{Discussions}

\subsection{Desinging the Strategic Plans for the Implementation of the 2013 Curriculum}

Designing the strategic plans in the implementation of the 2013 curriculum was done in three steps: planning step, designing step, and legalization. Explanation on those three steps is presented as follows.

\subsubsection{Preparation}

In the preparation step, a special team that would design the strategic plans was appointed by the school principles which team consisted of the school stakeholders who worked and made coordinations related to the duty.

\subsubsection{Designing}

This step was initiated by reviewing the visions, missions, goals, environment analysis, program and plan determination, determination of funding and sources, setting the monitoring and evaluation system, and the last one was the documentation in the form of a book. The order of those activities includes;

Firstly, reviewing the visions, missions, and the goals of the school. Visions, missions and goals of the three schools were different since they were made to fit certain characteristics of the schools and the target of those schools. Determination of visions was intended to give orientation for the future of the school. In the other words, visions refer to the future orientation of the school. Meanwhile, mission specifically emphasizes on the real product for 
the consumers and other aspects which are directly related to the educational services. Goals refer to the determination of specific measurable targets which the school desire to achieve within a certain time. Vision is the futuristic, deep, and wide view which comes from the abstract thought which are quite powerful to conquer physical, time, and place limit. Thus, vision is the key to powerful energy for human, leaders, and policy makers. Vision is also seen as an innovation in the process of strategic managmenet since lately vision has been confirmed to have dominant contribution to the policy making including the making of cetain strategy. Hergerson (Nawawi, 2000: 155) stated that vision is the picture of the future desired by an organization. It is not yet visible in the present time, yet the vision is a concept that is imaginable for each of the organization memeber. Vision has the power to invite, call, and tell every member to come and achieve the desired future. Organizational vision should be determined by the top managers of the organization. Furthermore, Naisibit (Nawawi, 2000:155) also mentioned that vision is a clear picture of what to achieve completed with details and instruction of actions to achieve it. A vision is regarded effective when it is able to offer satisfaction and regard the past experiences as the starting point to achieve the future. In line with the statement, Nawawi (2000: 155) stated that organizational vision can be explained as a point of view to the future and the realization of the strategic goals of the organization which has direct effects to the present mission and the future as well. Wahyudi (1996: 26) added up that vision is the wishes that the members of an organization want to achieve in the future. Vision is also the dream to achieve in the next 5, 8 or 10 year.

Secondly, the environemental analysis. Environmental analysis basically refers to the considerations in the determination of the school visions. Duncan et.al (1995), Katsioloudes (2002) stated that strategic management is the steps taken by the leaders of an organization to systematically run the organizational programs. The steps include an analysis on the surroundings of the organization which should also spot the sign of opportunities and threats around the organization. The next step is the analysis on the strengths and the weaknesses of the intern side of the organization. Those two steps should be conducted to determine the visions, missions and the goals of the organization.

Thirdly, designing the programs and plans. Programs and plans are important aspects to consider in the strategic plans which are able to give clear picture of what to do in certain period of time. Strategic plans involves any events that happen in quite a while, as stated by CSDF (1998) that strategic plan is defined as a long-term terminology, a future-oriented assessment process, determination of goals, developing the strategies that explicitly map the path between the present time and the future vision which rely on the precise consideration of the capability of the organization and its environemnet and that require the implementation of priority-based to the fund allocation and to any other decision making.

Fourth, determination of funding plan and sources. Financial plan is a program stated in currency which each is explained in details related to the fund that can be used by the management to make plans and control the organizational activities. Financial plan does not only provide detailed plan of the new strategies used in certain program, but it also goes together with financial report to show the intended effects of certain financial state of an organization. 
Fifth, setting the monitoring and evaluation system. It is stated by Hunger and Wheelen (2001: 19) that evalation and monitoring are the process in which any organizational activities and performance are being monitored which results are then compared to the target result. Managers in any level in an organization always use the information on the performance evaluation to help them deciding the enhancement and solutions toward the problems. Even though evaluation and monitoring appear to be the las element of the strategic management, this element has the ability to pricisely show the weaknesses of the previous strategy implementation, which drives enhancement to the whole system.

Sixth, documentation in the form of a book. Strategic plan which has been arranged and reviewed by the development team is then printed in the form of a book. The book contains information related to the plan of any programs that will be run by the school in a certain period of time. The strategic plan document is quite beneficial if it is able to describe the present situation of the school and can explain the goals to achieve in the future. In this case, the Texas Workforce Commission (2005) mentioned that "successful strategic plans are working documents that explain where you are going and promote the constructive change that will get you there". In a more detailed way, Unaso, 2003 said that strategic plan refers to the process to determine; (1) what to achive by an organization; (2) how the organization manage its resources to achieve the goals within months or years. Whilst, Suno (2010) highlighted that strategic plan is a map that directs an organization to move from the present condition to the condition of the next five or ten years.

\subsubsection{Legalization}

By legalizing the document, the strategic plan has to be implemented. Bryson (2004) explained that strategic plan is a strong attempt to produce certain decision and action that shape and guide the organization to do certain programs and the reason for doing it.

\subsection{Penerapan Strategi Dalam Implementasi Kurikulum 2013}

Based on the result of the focus II of this study on the application of the strategy in the implementation of the 2013 curriculum, it is found that there are five aspects identified which are; creating the curriculum document, developing the capability of the teachers and employees, fulfilling the appropriate facilities, funding and changing the school culture. Each of those points is explained as follows.

\subsubsection{Creating the Curriculum Document}

The curriculum document created by the development team contains; a. Visions, missions and goals; b. Strucure and the content of the curriculum, c. Learning expenses, d) standards of class promotion, mutation, treatments given to non-promoted students, and e. Academic calendar.

\subsubsection{Professional Development for Teachers and Employees}

Appropriate number of teachers and employees and any trainings, workshops held are important aspects to enhance the compentence. Within the scope of education institution, organizational culture puts human as the central aspect or the key aspect that determines the 
success of the organization. Therefore, human resources owned by an organization should be supported to develop their knowledge, skills, competence and manners related to their job; giving education services to the students. In addition, problem solving competence should be enhanced to anticipate any present challenges as well as future problems that might appear as the side effect of globalization faced by the insistutions.

\subsubsection{Fulfillment of Appropriate Facilities}

Appropriate facilities are able to give positive support to the teaching and learning activities. Facilities are important parts that support the implementation of certain strategic management. The development of an organization strongly relies on the capability of the leaders in managing and nurturing the members to achieve the organizational goals. Thus, the key points to the implementation of strategic management are (1) the fulfillment of national-standardized and international-standardized facilities which supports a school to achieve its goals; (2) creating favorable working environment which is considered conducive, communicative and in line with the predetermined working procedure as agreed by the National Education Department; (3) the realization of the excellent service values by all of the workers in the department; (4) the implementation of certain organizational system that is able to run the organizational programs; (5) the availability of fund needed to run the program effectively and efficiently; (6) the implementation of continued and sustainable evaluation to guarantee the accountability of the institution's performance.

\subsubsection{Funding}

Fund can be obtained from the government, society, donation, business center, and so on. Meanwhile, the allocation of the fund is classified into direct cost, indirect cost, and other costs.

\subsubsection{Changing the School Culture}

School cultural change is indicated by favorable environmental clture and good reading habit, good school culture and islamic culture as well as good achievement and adequate mardiwiyata knowledge. In order to have good culture, a school implements rules for teachers, employees and the students, followed with adjustment activities. The rules are necessary as the bond and guidance for the member of the school to behave and do educational activities. In this context, Huda (2010) said that in order to achieve effective education, a school needs to apply a set of rules that has to be obeyed by any of the school members that allows any interests from other members to be well-maintained and well-guaranteed to achieve the goals of the school.

\subsection{Evaluation on the Strategies Applied to the Implementation of the 2013 Curriculum}

Evaluation is regarded as a process of data collection up to data analysis, which is mentioned by Grondlund (1982) as a systematic process of data collection, data analysis, and data interpretation to see how far the students have achieved the goals of the learning. Cronbach (1990) defined evaluation in a broader scope as the data collection and the use of certain information to make policies related to educational programs. He also mentioned that 
evaluation is also beneficial for the program development.

The result of the third focus of this study on the evaluation of the strategy used in the implementation of the 2013 curriculum included three aspects; the success of the 2013 curriculum implementation, problems found during the implementation of the 2013 curriculum, and the solutions toward the problems. Those three aspects are correlated each other and all of them are directed at the optimalization of the success of the 2013 curriculum implementation. It is stated by Rusman (2011) that significant and sustainable evaluation is necessary to support an effective and meaningful curriculum development. From the result of the evaluation, revisions and adjustments can be made before the curriculum is launched as stated by Sonhadji and Huda (2014) that monitoring, evaluation and reporting are essential steps to see the degree of success of certain program. Each of those points is explained as follows.

\subsubsection{The Success of the 2013 Curriculum Implementation}

The success of the 2013 curriculum implementation covers: Good socialization; implementation that goes in line with the guidance, principles and procedures; Material analysis; Appropriateness of lesson planning, The use of suitable teaching approach and method; Authentic assessment; Corordination; The community of target schools for 2013 curriculum pilot project; and The appropriateness of the report. The degree of success of those aspects indicates the success of the strategic management implementaion. Saud (2005) divieds the indicators into (1) clear distribution of authority and responsibility in administering the school programsl (2) professional and democratic leadership that allows participative and transparent decision making by the school principal and the school managers; (3) the appropriateness of available facilities to support the school programs; (4) high quality of work and performance of the teachers and the school principal in doing daily duties and (5) high particpation and support from the local stakeholders, especially from parents and society toward the success of the school programs from any aspects.

\subsubsection{Problems Found in the Implementation of the 2013 Curriculum}

Problems found in the implementation of the 2013 curriculum included; Mindset shitfting; Limited preparation time; Not yet optimal material development; Lack of teaching media; Inappropriate use of evaluation technique; and the Mangament of programs and fund.

\subsubsection{Solutions for the Problems Found in the Implementation of the 2013 Curriculum}

The solutions toward those problems included; professional development training held for teachers and employees; Effectiveness of the teachers' expense; Scale of Priority; Reviewing the materials and designing modules; non-stop innovation programand the application of theme-based evalu91ation. Various solutions taken by the school to address the problems faced during the implementation of the 2013 curriculum are directed to achieve the objective of the 2013 curriculum. ;

\section{Conclusions}

Based on the result of the data analysis and the discussion of this study, the researcher draws 
some conclusions as follows. Firstly, the strategic plan in the implementation of the 2013 curriculum is desinged through these following steps: (1) Planning, which appears to be the first step of the activity. In this step, the school principal sets up a special team to design the plan supported by legal letter of decision. The team consists of representatives of the school stakeholders including the school principal, teachers, school committee, parents, leaders of the society, and other important persons. The initial activities done by the team is doing coordination meeting to set the schedules; (2) Designing activity starts with reviewing the visions, missions and the goals of the school, analyzing the intern environment, determining programs and events, determining the funding plan and sources, and determining the monitoring and evaluation system. This step is closed by documenting the strategic plan in the form of a book and (3) Legalization is the last step of the strategic planning. In this step, the final strategic plan is signed and legalized by the school, School Committee, the Head of the Branch of Education Department, and the Head of the Education Department to be legally regarded as the guidenace to implement the curriculum. Secondly, the application of the strategic plan in the implementation of the 2013 curriculum which involves some activities: (2) Designing the curriculum document by the curriculum development team appointed by the school principal that holds the main duty to review the 2013 curriculum, collect any related data to the curriculum desingning based on the applied procedures. Firstly, the curriculum documents created by the curriculum development team contain: 1) Visions, missions and goals; 2) Structure and content of the cirriculum; 3) Learning expenses; 4) Standard of class promotion, mutation, graduates, treatments for non-promoted students; and 5) Academic calendar; (2) Teachers and employees are regarded as important aspects in the implementation of the 2013 curriculum who need to be well-prepared in terms of the quantity and the quality and well-developed in terms of the competences. For the optimization of the 2013 curriculum implementation, teachers and employees should be given opportunities and supports to improve their competence; (3) fulfillment of appropriate facilities to support the teaching and learning activities is quite important since the 2013 curriculum demands utilization of advanced facilities (4) Funding should be well-considered since it is the energy to administer school programs and it should be well-planned in the school funding plans. Generally, school fund comes from the government, society, donation, school business center and others. Meanwhile, the allocation of the fund is classified into direct cost, indirect cost, and other costs; and (5) Changing the school culture appears as a logic consequence that follows the implementation of the 2013 curriculum. Hence, the school needs to interpret and practice the change based on the characterisctics of the school. In this study, the adjustment of the environment culture, school culture, reading habit, islamic culture, achievement and mardiwiyata knowledge are identified. To apply those cultural changes, the school needs to apply a set of rules for the teachers, employees as well as students, and the school has to administer adjustment activities or events. Thirdly, evaluation on the strategy applied in the implementation of the 2013 curriculum is intended to see the degree of success, problems and solutions to the problems. By determining the solutions to the problems, any problems that might occur can be regularly solved to prevent them from affecting the teaching and learning activities. (1) The result of this study shows that the success of the 2013 curriculum implementation covers: socialization and understanding the concept of the 2013 curriculum 
should be well-administered and should cover the targets; the implementation has been done according to the correct guidance, principles, and procedures; the material analysis activity has given positive effect to the improvement of teachers' comprehension on the content of the 2013 curriculum; lesson planning has been done in accordance to the guide; effective and efficient teaching approach and method has been implemented as well as authentic assessment; coordination across instution has been done, even some schools are included in a community of the target primary schools of 2013 curriculum pilot project; the report of the 2013 curriculum implementation also has been appropriately arranged; (2) Problems occured in the implementation of the 2013 curriculum include; the process of mindset shifiting that required time since teachers and employees had been used to implement the previous curriculum in quite a long period; limited time to do teaching and learning preparation becomes a mainstream problem faced by the teachers; the material development is also considered not yet optimum; lack of teaching media; inappropriate use of evaluation technique especially for the final exam; In the other side, the school management also dealt with problems related to program administration and funding, and (3) solutions for those problems include: conducting professional training and workshop for teachers and employees to impeove their competences which can be done in certain day or specific time; improvement on the effectiveness of teachers' expense; the implementation of priority scale toward the planned programs; conducting review on the materials and creating modules; enhancing the non-stop innovation program that allows teachers to express their creativity and innovations especially in creating teaching media; and the implementation of theme-based evaluation.

\section{References}

Akdon. (2011). Strategic Management: For Educational Management. Bandung Alfabeta.

Arifin, I. (2008). Kepemimpinan Kepala Sekolah dalam Mengelola Sekolah Berprestasi, Studi Multi Kasus pada MIN Malang I, MI Mambaul Ulum, dan SDN Ngaglik Batu Malang. Yogyakarta: Aditya Media Publishing.

Bafadal, I. (2012). Manajemen Peningkatan Mutu Sekolah Dasar dari Sentralisasi Menuju Desentralisasi. Jakarta: PT. Bumi Aksara.

Bintari, N. A. A. (2015). Pengelolaan Evaluasi Pembelajaran Kurikulum 2013 di SD Negeri Salatiga 06. Tesis tidak diterbitkan. Semarang: Program Studi Magister Pendidikan, Universitas Muhammadiyah Surakarta.

Bogdan, R. C., \& Biklen, S. K. (1998). Qualitative Research in Education and Introduction Theory and Methods. USA: Library of Congress Cataloging -in publication Date.

Bryson, J. M., \& Alston, F. K. (2005). Creating and Implementing Your Strategic Plan: a Workbook for Public and Non Profit Organizations. San Fransisco: Jossey Bass.

Buford, Jr. J. A., \& Bedeian, A. G. (1988). Management in Extension. Auburn: Auburn University.

Creswell, J. W. (1994). Research Delign: Qualitative ond Quantitative Approaches. USA: 


\section{Macrothink}

Library of -congis cu,otogirrg-in-pubrication Date.

Cronbach, L.J. (1990). Essentials of Psychological Testing (5th ed.). New York: Harper and Row Publishers

CSDF. (1998). Strategic Planning Guidelines. California: California State Departemen of Finance (CSDF).

Duncan, J. W. (1981). Orgonizational Behaviour. Boston: Houghton Mifflin co.

Fremont K., E., \& dan Rosenzweig, E., J. (1970). Organization And Management, System Approoch. New York : Mc Graw-Flill Book Company.

Gaspersz, V. (2007). Organizational Exellence. Jakarta: PT. Gramedia.

Glanz, E. C. (2004). Guidanve: Fondation, Principles, and Techniques (2nd ed.). Boston: Allyn Bacon, Inc.

Glaser, B. G., \& Strauss, A. L. (1967). The Discovery of Grounded Theory. Chicago: Aldine.

Goetz, J. P., \& Le Compte, M. D. (1981). Ethnographic Research And The Problem Of Data Reduction. Anthropology and Education Quarterly, Orlango: Academic Press Inc.

Grondlund, N. E. (1982). Constructing Achievement Test (3rd ed.). En-glewood Cliffs, NJ: Prentice-Hall, Inc.

Guba, E. G., \& dan Yvonna S. L. (1981). Evective Evaluation, Improving The Usefullness Of Evaluation Results Trough Responsive And Naturalistic Approaches. San francisco: Jossey-Bass Publihers.

Hersey, P., \& Blanchard, K. (1997). Management of Organization Behaviour: Utilizing Human Resources. New Jersey: Engewood Cliffs Prentice Hall Inc.

Hoy, W. K. \& Miskel, G. C. (2001). Educational Administration, Theory, Research and Practice. Singapore : McGraw-Hill.

Huda, M. (2010). Kajian Filosofis Otonomi Daerah Bidang Pendidikan. Malang: FIP-UM

Hunger, D. J., \& dan Wheelen, T. L. (1996). Strategic Management (5th ed.). New York: Addison-Wesley Publishing Company.

Kreitner, R., \& Angelo, K. (1995). Organizational Behavior, Edisi Ketiga. USA: D. Irwin, Inc.

Lee, J. M., \& Pallone. (2006). Guidance and Counseling is Schools Foundations and Process. New York: Graw-Hill Book Company.

Lexy, M. L. (2000). Metodologi Penelitian Kualitatif. Bandung: Remadja Rosda Karya.

Miles, H. B., \& Hubbernern, A. M. (1984). Qualitative Data Analysis a Sources book.

Miller, J. P., \& dan Saller, W. (1985). Curriculum Perspective and Practice. New York and London: Longman. 


\section{Macrothink}

International Journal of Learning and Development

ISSN 2164-4063 2017, Vol. 7, No. 3

Nawawi, H. (2000). Manajemen Strategik Organisasi Non Profit Bidang Pemerintah dengan Ilustrasi di Bidang Pendidikan. Yogyakarta: Gadjah Mada University Press.

Oliva, P. (1992). Developing Principles and Foundation (2nd ed.). New South Wales, Australia: Allen \& Unwim.

Peraturan Pemerintah Republik Indonesia Nomor 13 Tahun 2015 tentang Perubahan Kedua atas Peraturan Pemerintah Nomor 19 Tahun 2005 tentang Standar Nasional Pendidikan.

Peraturan Pemerintah Nomor 19 Tahun 2005 tentang Standar Nasional Pendidikan

Robbins, S. P. (2003). Organizational Behaviour, (Terjemahan oleh Tim Indeks), Rusman. (2011). Manajemen Kurikulum. Jakarta: Rajawali Pers.

Siagian, S. (2005). Manajemen Stratejik, Edisi Keenam. Jakarta: PT. Bumi Aksara.

Sonhadji, A. (2012). Manusia, Teknologi, dan Pendidikan Menuju Peradaban Baru. Malang: Penerbit Universitas Negeri Malang (UM Press).

Sonhadji, A., \& dan Huda, M. (2014). Asesmen Kebutuhan, Pengambilan Keputusan, dan Perencanaan. Malang: Universitas Negeri Malang

Sonhadji, A. (2015). Membangun Peradaban Bangsa dalam Perspektif Multikultural, Potensi Indonesia Menjadi Negara Besar. Malang: Universitas Negeri Malang

SUNO. (2010). Strategic Planning Handbook and Managers Implementation Tools. New Orleans: Shouthern University at New Orleans (SUNO).

Terry, G. R. (2008). Principles of Management (7th ed.). Homewood Illionois: Richart D. Irwin, Inc.

Texas Workforce Commission. (2005). Strategic Planning: Managing Strategically. Texas: Texas Workforce Commission.

Triwiyanto, T. (2015). Manajemen Kurikulum dan Pembelajaran. Jakarta: Bumi Aksara.

UNASO. (2003). Strategic Management: Trainer's Guide. Uganda: Uganda Network of AIDS Service Organisations (UNASO). Undang- Undang Republik Indonesia Nomor 20 Tahun 2003 tentang Sistem Pendidikan Nasional dan penjelasannya, Bandung: Citra Umbara Usman, H. (2006). Manajemen, Teori, Praktik, dan Riset Pendidikan. Jakarta: PT.Wiley \& Sons.

Wahyudi, A. S. (1996). Manajemen Strategik. Jakarta: Binarupa Aksara.

\section{Copyright Disclaimer}

Copyright for this article is retained by the author(s), with first publication rights granted to the journal.

This is an open-access article distributed under the terms and conditions of the Creative Commons Attribution license (http://creativecommons.org/licenses/by/4.0/). 